\title{
Factors Associated with Perforated Appendicitis in Elderly Patients in a Tertiary Care Hospital
}

\author{
Siripong Sirikurnpiboon and Suparat Amornpornchareon \\ Department of Surgery, Rajavithi Hospital, College of Medicine, Rangsit University, Phayathai Road, Rajathewee, \\ Bangkok 10400, Thailand
}

Correspondence should be addressed to Siripong Sirikurnpiboon; laizan99@hotmail.com

Received 22 May 2015; Revised 3 August 2015; Accepted 10 August 2015

Academic Editor: Miltiadis I. Matsagkas

Copyright (C) 2015 S. Sirikurnpiboon and S. Amornpornchareon. This is an open access article distributed under the Creative Commons Attribution License, which permits unrestricted use, distribution, and reproduction in any medium, provided the original work is properly cited.

\begin{abstract}
Background. The incidence of perforated appendicitis in elderly patients is high and carries increased morbidity and mortality rates. The aim of this study was to identify risk factors of perforation in elderly patients who presented with clinical of acute appendicitis. Methods. This was a retrospective study, reviewing medical records of patients over the age of 60 years who had a confirmed diagnosis of acute appendicitis. Patients were classified into two groups: those with perforated appendicitis and those with nonperforated appendicitis. Demographic data, clinical presentations, and laboratory analysis were compared. Results. Of the 206 acute appendicitis patients over the age of 60 years, perforated appendicitis was found in 106 (50\%) patients. The four factors which predicted appendiceal rupture were as follows: male; duration of pain in preadmission period; fever $\left(>38^{\circ} \mathrm{C}\right)$; and anorexia. The overall complication rate was $34 \%$ in the perforation group and $12.6 \%$ in the nonperforation group. Conclusions. The incidence of perforated appendicitis in elderly patients was higher in males and those who had certain clinical features such as fever and anorexia. Duration of pain in the preadmission period was also an important factor in appendiceal rupture. Early diagnosis may decrease the incidence of perforated appendicitis in elderly patients.
\end{abstract}

\section{Introduction}

Acute appendicitis is the most common surgical disease, with an incidence of about 100 per 100,000 . The life-time risk of developing appendicitis is $8.6 \%$ for males and $6.7 \%$ for females $[1,2]$, with $90 \%$ found in children and young adults and $10 \%$ in patients over 60 years old $[3,4]$.

Diagnosis of appendicitis is made mainly by history and physical examination, and laboratory study and radiologic investigation are helpful in equivocal cases. Clinical presentation has overall sensitivity and specificity of $45-81 \%$ and $36-53 \%$ [5], respectively. The possible cause is variation of appendix [6]. With regard to laboratory study, an increase in white blood cell count (WBC), predominance of polymorphonuclear leukocytes (PMN), and increased C-reactive protein (CRP) levels were associated with the risk and severity of complications in appendicitis [7]. With elderly patients, the diagnosis is more difficult, and this can lead to higher mortality and morbidity rates than in the general population.
This study aimed to analyse factors associated with rupture in elderly patients.

\section{Materials and Methods}

This was a retrospective study of medical records which were searched for ICD-10: K35 diagnosis codes from January 2010 to December 2014. The inclusion criteria were patients who (1) had diagnosis of acute appendicitis; (2) who were aged more than 60 years; (3) who had undergone operation in Rajvithi Hospital; and (4) whose pathological results had confirmed appendicitis. Patients who had undergone appendectomy inadvertently or whose type of appendicitis (acute appendicitis or perforated appendicitis) could not be identified from medical records or pathological reports were excluded. Each case underwent open appendectomy, and drains were placed in all patients in the perforated group. Data collected included demographic data, clinical presentation, duration of pain in the preadmission period, and 
TABLE 1: Comparison of patients' characteristics in the perforated and nonperforated appendicitis groups.

\begin{tabular}{|c|c|c|c|}
\hline & Perforated appendicitis $(n=103)$ & Nonperforated appendicitis $(n=103)$ & $p$ value \\
\hline Age (mean $\pm \mathrm{SD})$ (years) & $68.8 \pm 7.4$ & $69.2 \pm 6.8$ & 0.989 \\
\hline Male sex & $49(47.6)$ & $29(28.2)$ & $0.004^{*}$ \\
\hline Address & & & $<0.001^{*}$ \\
\hline Urban & $74(71.9)$ & $36(35.0)$ & \\
\hline Suburb & $29(28.1)$ & $67(65.0)$ & \\
\hline Living status & & & $<0.001^{*}$ \\
\hline With family & $82(86.3)$ & $30(29.1)$ & \\
\hline Living alone & $13(13.7)$ & $63(70.9)$ & \\
\hline Underlying disease & & & 0.770 \\
\hline Diabetes mellitus & $32(31.1)$ & $25(24.3)$ & 0.276 \\
\hline Hypertension & $56(54.4)$ & $54(52.4)$ & 0.780 \\
\hline Myocardial infarction & $10(9.7)$ & $11(10.7)$ & 0.818 \\
\hline Congestive heart failure & $1(1.0)$ & $2(1.9)$ & 1.000 \\
\hline Chronic kidney disease & $8(7.8)$ & $5(4.9)$ & 0.390 \\
\hline Chronic liver disease & $0(0)$ & $2(1.9)$ & 0.498 \\
\hline COPD & $3(2.9)$ & $3(2.9)$ & 1.000 \\
\hline ASA classification & & & 0.218 \\
\hline I & $11(10.7)$ & $8(7.8)$ & \\
\hline II & $76(73.8)$ & $86(83.5)$ & \\
\hline III & $16(15.5)$ & $9(8.7)$ & \\
\hline $\mathrm{BMI}($ mean $\pm \mathrm{SD})(\mathrm{Kg})$ & $23.8 \pm 4.2$ & $23.9 \pm 3.3$ & 0.525 \\
\hline
\end{tabular}

$*$ : value $<0.05$ is statistically significant.

laboratory analysis. Statistical analysis was performed using univariate and multivariate logistic regression with SPSS version 17.0.

\section{Results}

Appendectomies were performed from 1 January 2010 to 31 December 2014 on 206 patients who were all more than 60 years old. Of these cases, 78 were males $(37.9 \%)$ and 128 were females $(62.1 \%)$. The mean age was $68.98 \pm 7.08$ years $(60-91$ years), and the mean BMI was $23.86 \pm 3.76$ (16.4-37.0). Half (103) of the appendectomies were perforated, and half (103) were nonperforated.

A total of 125 patients $(60.7 \%)$ had comorbidity such as diabetes mellitus, hypertension, chronic kidney disease, chronic liver disease, cardiovascular disease, congestive heart failure, and COPD, and 71 patients had more than one comorbidity. A comparison of the basic characteristics of the groups is shown in Table 1. It was found that perforated appendicitis was associated with male sex, living in urban areas, and living alone.

With regard to clinical presentation, most patients with abdominal pain had other symptoms such as nausea, vomiting, anorexia, migratory pain from the periumbilicus to the right iliac fossa, and fever $\geq 38^{\circ} \mathrm{C}$. Physical examination showed tenderness at the right iliac fossa, and laboratory data revealed an increase in WBC and PMN predominance. Imaging studies were done by CT (computerized tomography) scan or US (ultrasonography), and 2 patients in the perforated group and 1 in the nonperforated group underwent both. In the perforation group, the mean time to imaging was 8.53 hours (1-24 hours) while in the nonperforated group it was 5.33 hours (2-12 hours). The clinical data of the two groups are compared in Table 2 . Clinical presentation data showed that anorexia, fever of more than $38^{\circ} \mathrm{C}$, and time to imaging were significantly associated with perforated appendicitis. The overall median duration of pain in the preadmission period was 24 hours (2-240 hours). Most of the patients came to the hospital 24 hours after the onset of abdominal pain. Of these, $90(87.4 \%)$ had perforated appendicitis and 66 (64.1\%) had acute appendicitis. The study showed there were statistically significant differences between the two groups. The overall median duration of pain to performance of operation was 28.5 hours (4-241.5 hours); in the perforated group the mean duration was 50 hours and in the nonperforated group it was 27 hours $(p<0.01)$, and this was a statistically significant difference. Patients who underwent imaging more than 6 hours after arriving at the hospital had a significantly higher risk of perforation. Details are shown in Table 3.

With regard to intraoperative result, 6 patients in perforated group had conversion operations: 2 to right hemicolectomy and 4 patients to ileocecectomy. Univariate analysis showed that the factors associated with perforated appendicitis were male sex, fever $\geq 38^{\circ} \mathrm{C}$, anorexia, duration of pain in the preadmission period, and duration of pain to performance of operation. Multivariate analysis revealed that the factors significantly associated with perforated appendicitis were male sex $(\mathrm{OR}=2.36,95 \% \mathrm{CI}, 1.25-4.44)$, fever $\geq 38^{\circ} \mathrm{C}$ 
TABLE 2: Comparison of clinical presentation in the two groups.

\begin{tabular}{|c|c|c|c|}
\hline Clinical presentation & $\begin{array}{l}\text { Perforated appendicitis } \\
\quad(n=103)(\%)\end{array}$ & $\begin{array}{l}\text { Acute appendicitis } \\
\quad(n=103)(\%)\end{array}$ & $p$ value \\
\hline Nausea and/or vomiting & $67(65)$ & $60(58.3)$ & 0.316 \\
\hline Anorexia & $65(63.1)$ & $50(48.5)$ & $0.035^{*}$ \\
\hline Migratory pain & $60(58.3)$ & $58(56.3)$ & 0.778 \\
\hline Fever $>38^{\circ} \mathrm{C}$ & $44(42.7)$ & $26(25.2)$ & $0.008^{*}$ \\
\hline RLQ tenderness & $102(99)$ & $103(100)$ & 1.000 \\
\hline Rebound tenderness & $91(88.3)$ & $83(80.6)$ & 0.124 \\
\hline $\mathrm{WBC}>10 \times 10^{9} \mathrm{cell} / \mathrm{L}$ & $87(84.5)$ & $89(86.4)$ & 0.693 \\
\hline Neutrophil > 75\% & $74(71.8)$ & $83(80.6)$ & 0.141 \\
\hline Alvarado score (mean \pm SD) & $7.58 \pm 1.49$ & $7.29 \pm 1.36$ & 0.199 \\
\hline Imaging study & $31(48.4)$ & $33(51.6)$ & 0.763 \\
\hline Computerized tomography & $22(21.4)$ & $22(21.4)$ & 1.000 \\
\hline Acute appendicitis & $4(18.2)$ & $21(95.5)$ & $<0.001^{*}$ \\
\hline Ruptured appendicitis & $18(81.8)$ & $1(4.5)$ & \\
\hline Ultrasonography & $11(10.7)$ & $12(11.7)$ & 0.825 \\
\hline Acute appendicitis & $6(54.5)$ & $12(100.0)$ & $0.024^{*}$ \\
\hline Ruptured appendicitis & $5(45.5)$ & $0(0.0)$ & \\
\hline Time to imaging $($ mean $\pm S D)$ & $8.53 \pm 3.57$ & $5.33 \pm 2.33$ & $<0.001^{*}$ \\
\hline
\end{tabular}

$*$ : value $<0.05$ is statistically significant.

TABLE 3: Duration of time in perforated and acute appendicitis groups.

\begin{tabular}{|c|c|c|c|}
\hline & $\begin{array}{l}\text { Perforated appendicitis } \\
\qquad n=103\end{array}$ & $\begin{array}{l}\text { Acute appendicitis } \\
\quad(n=103)\end{array}$ & $p$ value \\
\hline Duration of pain in admission period & $48(6-240)$ & $24(2-96)$ & \multirow{3}{*}{$<0.001^{*}$} \\
\hline$<24$ hours & $13(12.6 \%)$ & $37(35.9 \%)$ & \\
\hline$\geq 24$ hours & $90(87.4 \%)$ & $66(64.1 \%)$ & \\
\hline Duration from pain to operation & $50(8-241)$ & $27(4-104)$ & \multirow{3}{*}{$<0.001^{*}$} \\
\hline$<24$ hours & $11(10.7 \%)$ & $35(34.0 \%)$ & \\
\hline$\geq 24$ hours & $37(89.3 \%)$ & $46(66.1 \%)$ & \\
\hline Duration from admission to operation & $6(1-8)$ & $10(9-12)$ & \multirow{3}{*}{0.416} \\
\hline$>8$ hours & $16(15.5 \%)$ & $12(11.7 \%)$ & \\
\hline$\leq 8$ hours & $87(84.5 \%)$ & $91(88.3 \%)$ & \\
\hline Duration from arrival to imaging & $8(1-24)$ & $6(2-12)$ & \multirow{3}{*}{$<0.001^{*}$} \\
\hline$>6$ hours & $78(75.7)$ & $30(29.1)$ & \\
\hline$\leq 6$ hours & $25(24.3)$ & $73(70.9)$ & \\
\hline
\end{tabular}

Value $s$ are represented as numbers (percentages) and median (minimum-maximum).

$*$ : value $<0.05$ is statistically significant.

$(\mathrm{OR}=2.17,95 \% \mathrm{CI}, 1.10-4.27)$, anorexia $(\mathrm{OR}=1.92,95 \% \mathrm{CI}$, 1.03-3.57), and duration of pain in the preadmission period $(\mathrm{OR}=1.02,95 \% \mathrm{CI}, 1.01-1.04)$. Details are shown in Table 4.

The total number of complications was $34(33 \%)$ in the perforated appendicitis group compared with 13 (12\%) in the acute appendicitis patients $(p<0.001)$. Significant complications were pneumonia $(p=0.046)$ and surgical wound infection $(p=0.001)$. Median length of hospital stay in the perforation group was 8 days (3-48 days) and 4 days (2-136 days) in the nonperforation group, and this was statistically significant $(p<0.001)$. Of the 103 patients in the perforated appendicitis group, there were 92 cases $(89.3 \%)$ of complete recovery and two mortalities (1.9\%): one patient died from septic shock 10 days after the onset of abdominal pain due to delayed diagnosis, and the other one died from congestive heart failure due to multiple comorbidities and underlying valvular heart disease. In contrast, complete recovery was observed in all nonperforated patients, and there were no mortalities. A comparison of morbidity and mortality in the two groups is shown in Table 5.

An analysis of scores for predicting ruptured appendicitis is shown in Table 6. Validation scores using cut-off value 6 in this data showed sensitivity of $56 \%$ with specificity of $83 \%$ and accuracy of $69.4 \%$ as shown in Table 7. 
TABLE 4: Factors associated with perforated appendicitis by multivariate analysis.

\begin{tabular}{lccc}
\hline Factor & Adjusted odds ratio & 95\% confidence interval & $p$ value \\
\hline Male sex & 2.47 & $1.31-4.63$ & 0.008 \\
Fever $>38^{\circ} \mathrm{C}$ & 1.97 & $1.03-3.78$ & 0.024 \\
Anorexia & 1.90 & $1.03-3.52$ & 0.040 \\
Duration of pain in preadmission period & 4.21 & $2.22-7.98$ & $<0.001$ \\
\hline
\end{tabular}

TABLE 5: Outcomes, complications, and length of hospital stay.

\begin{tabular}{|c|c|c|c|}
\hline Results & $\begin{array}{l}\text { Perforated appendicitis } \\
\qquad(n=103)\end{array}$ & $\begin{array}{l}\text { Acute appendicitis } \\
\qquad(n=103)\end{array}$ & $p$ value \\
\hline Operation conversion $n(\%)$ & $8(7.8)$ & 0 & $0.003^{*}$ \\
\hline Complication $n(\%)$ & $34(33)$ & $13(12.6)$ & $<0.001^{*}$ \\
\hline Pneumonia & $16(15.5)$ & $7(6.8)$ & $0.046^{*}$ \\
\hline Respiratory failure & $4(3.9)$ & $1(1.0)$ & 0.174 \\
\hline Gastrointestinal bleeding & $2(1.9)$ & $0(0)$ & 0.498 \\
\hline Surgical wound infection & $19(18.4)$ & $4(3.9)$ & $0.001^{*}$ \\
\hline \multicolumn{4}{|l|}{ Length of hospital stay } \\
\hline Median (min-max) & $8(3-48)$ & $4(2-136)$ & $<0.001$ \\
\hline Discharge status $n(\%)$ & & & $0.005^{*}$ \\
\hline Complete recovery & $92(89.3)$ & $102(99)$ & \\
\hline Morbidity & $9(8.7)$ & $1(1)$ & \\
\hline Death & $2(1.9)$ & $0(0)$ & \\
\hline
\end{tabular}

$*$ : value $<0.05$ is statistically significant.

TABLE 6: Scores for predicting ruptured appendicitis in elderly patients.

\begin{tabular}{lcc}
\hline Factor & Adjusted OR & Score \\
\hline Male & 2.47 & 2 \\
Fever $\left(T>38^{\circ} \mathrm{C}\right)$ & 1.97 & 2 \\
Anorexia & 1.90 & 2 \\
Pain $>24$ hrs & 4.21 & 4 \\
Total score & & 10 \\
\hline
\end{tabular}

\section{Discussion}

The incidence of acute appendicitis in elderly patients aged more than 60 years was about $5-10 \%[3,8]$ with good postoperative outcome after appendectomy, but, in the case of perforated appendicitis, there were instances of mortality and higher rates of morbidity postoperatively. The incidence of perforated appendicitis was 32\%-72\% [9-14] mostly due to delayed diagnosis caused by equivocal history and physical examination [14-17]. In the present study, perforated appendicitis was found in $50 \%$ of cases which is comparable to the findings of previous research. The risk factors associated with perforated appendicitis were male sex, fever $\geq 38^{\circ} \mathrm{C}$, anorexia, and duration of pain in the preadmission period.

In relation to risk factors, this research found that being of male sex was significantly related to perforation, and this is in line with the results of previous reports [18-20]. A possible explanation for this is elderly males' culture of reluctance to go to hospital, as found in a report by Sheu et al. [18].
With regard to social factors, living in metropolitan areas and living alone were risks for delaying seeking medical services. The author did not attempt to delve into this factor in detail, but possible explanations are changes in family structure, an increase in living away from one's family, and less real social participation.

With regard to clinical presentation, fever $\geq 38^{\circ} \mathrm{C}$ and anorexia were factors affecting the likelihood of having a perforated appendix. Previous studies have shown the same significance of fever $[18,21,22]$. A recent report by Shimizu et al. [23] confirmed the relationship between severity of fever and appendicitis and proposed that the neutrophil to lymphocyte ratio (NLR) was useful for predicting the severity of inflammation because pooled neutrophils in bone marrow are able to respond more rapidly to infectious disease compared to acute inflammation-related proteins that are produced by the liver such as C-reactive protein. In relation to the Alvarado score, the mean in the perforation group was $7.58 \pm 1.49$ and $7.29 \pm 1.36$ in the nonperforation group. An Alvarado score of more than 7 had sensitivity and specificity for diagnosing appendicitis, but high Alvarado scores did not correlate with severity of disease and could not discriminate between perforated and acute appendicitis [24]. In this study, the median duration of pain in the preadmission period in the perforated appendicitis patients was 48 hours. The results confirmed the findings of previous reports about the risk of perforation from delaying seeking medical attention $[8,11,13,21,25-28]$. A recent study by Augustin et al. [29] showed that the risk of perforation increased 36 hours after onset of pain. Similarly, in a report about another age group, Singh et al. [30] showed 
TABLE 7: Validation scores for predicting ruptured appendicitis.

\begin{tabular}{|c|c|c|c|c|c|c|c|c|}
\hline & \multicolumn{2}{|c|}{ Perforation } & \multirow{2}{*}{ Total } & \multirow{2}{*}{ Sensitivity } & \multirow{2}{*}{ Specificity } & \multirow{2}{*}{ PPV } & \multirow{2}{*}{ NPV } & \multirow{2}{*}{ Accuracy } \\
\hline & Yes & No & & & & & & \\
\hline \multicolumn{9}{|l|}{ Score } \\
\hline$\geq 6$ & 58 & 18 & 76 & & & & & \\
\hline$<6$ & 45 & 85 & 130 & $58 / 103=56 \%$ & $85 / 103=83 \%$ & $58 / 7=76 \%$ & $85 / 130=65 \%$ & $143 / 206=69.4 \%$ \\
\hline Total & 103 & 103 & & & & & & \\
\hline
\end{tabular}

a significant association between perforated appendicitis in pediatric patients and a duration of pain to admission of longer than 72 hours. With regard to time to imaging, this was significantly longer in the perforated group compared to the nonperforated one. Generally, clinical examination is more important than investigation, but the latter can be helpful where the clinical picture is equivocal in patients of extreme age. A study from Gardner et al. [31] showed imaging influenced elderly patient management in $36 \%$ of cases and affected diagnosis; however, the impact of duration from admission to operation is still a controversial issue. A report by Eko et al. [32] suggested that it should not exceed 18 hours in order to reduce postoperative morbidities and length of stay. Busch et al. [33] showed that a delay of more than 12 hours was associated with a significant increase in the rates of perforation. In contrast, another study did not show any significant difference: Partelli et al. [34] reported that delays in performing appendicitis operations did not increase postoperative complications. Similarly, Abou-Nukta et al. [17] reported that delaying appendectomy by 12-24 hours after presentation did not significantly increase the rate of perforation, operative times, or length of stay; furthermore, a recent report by Teixeira et al. [35] found that delays in the time from diagnosis to operation did not increase perforation rates.

The mortality rate of perforated appendicitis in elderly patients was about $2.3 \%$ to $10 \%$ and most commonly correlated with infection and underlying comorbid disease $[8,11-$ 13]. In our study, there were 2 deaths (1.9\%) from sepsis and underlying comorbid disease, similar to the results of other studies.

One limitation of this study was that it was a retrospective one, so that we were unable to collect some significant data which could possibly have affected the outcomes, such as patient race, economic status, type of appendicitis, and CRP level.

\section{Conclusion}

Male sex, fever $\geq 38^{\circ} \mathrm{C}$, anorexia, and duration of pain in the preadmission period were the significant factors associated with perforated appendicitis in elderly patients in this study.

\section{Conflict of Interests}

The authors declare that there is no conflict of interests regarding the publication of this paper.

\section{References}

[1] S. I. Schwartz, G. T. Shires, F. C. Spencer, J. M. Daly, J. E. Fisher, and A. C. Galloway, Principles of Surgery, McGraw-Hill, New York, NY, USA, 7th edition, 1999.

[2] C. D. Liu and D. W. McFadden, "Acute abdomen and appendix," in Surgery: Scientific Principles and Practice, L. J. Greenfield, M. W. Mulholland, K. T. Oldham et al., Eds., pp. 1246-1261, Lippincott-Raven, Philadelphia, Pa, USA, 2nd edition, 1997.

[3] D. G. Addiss, N. Shaffer, B. S. Fowler, and R. V. Tauxe, "The epidemiology of appendicitis and appendectomy in the United States," The American Journal of Epidemiology, vol. 132, no. 5, pp. 910-925, 1990.

[4] C. L. Temple, S. A. Huchcroft, and W. J. Temple, "The natural history of appendicitis in adults: a prospective study," Annals of Surgery, vol. 221, no. 3, pp. 278-281, 1995.

[5] J. M. Wagner, W. P. McKinney, and J. L. Carpenter, "Does this patient have appendicitis?" The Journal of the American Medical Association, vol. 276, no. 19, pp. 1589-1594, 1996.

[6] J. Berry Jr. and R. A. Malt, "Appendicitis near its centenary," Annals of Surgery, vol. 200, no. 5, pp. 567-575, 1984.

[7] J. M. Grönroos and P. Grönroos, "Leucocyte count and Creactive protein in the diagnosis of acute appendicitis," British Journal of Surgery, vol. 86, no. 4, pp. 501-504, 1999.

[8] M. G. Franz, J. Norman, and P. J. Fabri, "Increased morbidity of appendicitis with advancing age," American Surgeon, vol. 61, no. 1, pp. 40-44, 1995.

[9] S. Lunča, G. Bouras, and N. S. Romedea, "Acute appendicitis in the elderly patient: diagnostic problems, prognostic factors and outcomes," Romanian Journal of Gastroenterology, vol. 13, no. 4, pp. 299-303, 2004.

[10] R. Rub, D. Margel, D. Soffer, and Y. Kluger, "Appendicitis in the elderly: what has changed?" Israel Medical Association Journal, vol. 2, no. 3, pp. 220-223, 2000.

[11] J. F. Y. Lee, C. K. Leow, and W. Y. Lau, "Appendicitis in the elderly," Australian and New Zealand Journal of Surgery, vol. 70, no. 8, pp. 593-596, 2000.

[12] P. G. Blomqvist, R. E. B. Andersson, F. Granath, M. P. Lambe, and A. R. Ekbom, "Mortality after appendectomy in Sweden, 1987-1996," Annals of Surgery, vol. 233, no. 4, pp. 455-460, 2001.

[13] D. J. Sherlock, "Acute appendicitis in the over-sixty age group," British Journal of Surgery, vol. 72, no. 3, pp. 245-246, 1985.

[14] R. Pieper, L. Kager, and P. Nasman, "Acute appendicitis: a clinical study of 1018 cases of emergency appendectomy," Acta Chirurgica Scandinavica, vol. 148, no. 1, pp. 51-62, 1982.

[15] D. J. FitzGerald and A. M. Pancioli, "Acute appendicitis," in Emergency Medicine-A Comprehensive Study Guide, J. E. Tintinalli, G. D. Kelen, and J. S. Stapczynski, Eds., pp. 520-523, McGraw-Hill, Columbus, Ohio, USA, 2003.

[16] D. R. Flum, A. Morris, T. Koepsell, and E. P. Dellinger, "Has misdiagnosis of appendicitis decreased over time? A 
population-based analysis," The Journal of the American Medical Association, vol. 286, no. 14, pp. 1748-1753, 2001.

[17] F. Abou-Nukta, C. Bakhos, K. Arroyo et al., "Effects of delaying appendectomy for acute appendicitis for 12 to 24 hours," Archives of Surgery, vol. 141, no. 5, pp. 504-507, 2006.

[18] B.-F. Sheu, T.-F. Chiu, J.-C. Chen, M.-S. Tung, M.-W. Chang, and Y.-R. Young, "Risk factors associated with perforated appendicitis in elderly patients presenting with signs and symptoms of acute appendicitis," ANZ Journal of Surgery, vol. 77, no. 8, pp. 662-666, 2007.

[19] T. L. Storm-Dickerson and M. C. Horattas, "What have we learned over the past 20 years about appendicitis in the elderly?" American Journal of Surgery, vol. 185, no. 3, pp. 198-201, 2003.

[20] A. H. Omari, M. R. Khammash, G. R. Qasaimeh, A. K. Shammari, M. K. B. Yaseen, and S. K. Hammori, "Acute appendicitis in the elderly: risk factors for perforation," World Journal of Emergency Surgery, vol. 9, article 6, 2014.

[21] D. Oliak, D. Yamini, V. M. Udani et al., "Can perforated appendicitis be diagnosed preoperatively based on admission factors?" Journal of Gastrointestinal Surgery, vol. 4, no. 5, pp. 470-474, 2000.

[22] P. Pruekprasert, A. Geater, P. Ksuntigij, T. Maipang, and N. Apakupakul, "Accuracy in diagnosis of acute appendicitis by comparing serum C-reactive protein measurements, Alvarado score and clinical impression of surgeons," Journal of the Medical Association of Thailand, vol. 87, no. 3, pp. 296-303, 2004.

[23] T. Shimizu, M. Ishizuka, and K. Kubota, "A lower neutrophil to lymphocyte ratio is closely associated with catarrhal appendicitis versus severe appendicitis," Surgery Today, 2015.

[24] R. Ohle, F. O’Reilly, K. K. O’Brien, T. Fahey, and B. D. Dimitrov, "The Alvarado score for predicting acute appendicitis: a systematic review," BMC Medicine, vol. 9, article 139, 2011.

[25] W. B. Smithy, S. D. Wexner, and T. H. Dailey, "The diagnosis and treatment of acute appendicitis in the aged," Diseases of the Colon and Rectum, vol. 29, no. 3, pp. 170-173, 1986.

[26] C. I. Ryden, T. Grunditz, and L. Janzon, "Acute appendicitis in patients above and below 60 years of age. Incidence rate and clinical course," Acta Chirurgica Scandinavica, vol. 149, no. 2, pp. 165-170, 1983.

[27] S. Eldar, E. Nash, E. Sabo et al., "Delay of surgery in acute appendicitis," American Journal of Surgery, vol. 173, no. 3, pp. 194-198, 1997.

[28] H. Körner, K. Söndenaa, J. A. Söreide et al., "Incidence of acute nonperforated and perforated appendicitis: age-specific and sex-specific analysis," World Journal of Surgery, vol. 21, no. 3, pp. 313-317, 1997.

[29] T. Augustin, B. Cagir, and T. J. VanderMeer, "Characteristics of perforated appendicitis effect of delay is confounded by age and gender," Journal of Gastrointestinal Surgery, vol. 15, no. 7, pp. 1223-1231, 2011.

[30] M. Singh, Y. Kadian, K. Rattan, and B. Jangra, "Complicated appendicitis: analysis of risk factors in children," African Journal of Paediatric Surgery, vol. 11, no. 2, pp. 109-113, 2014.

[31] C. S. Gardner, T. A. Jaffe, and R. C. Nelson, "Impact of CT in elderly patients presenting to the emergency department with acute abdominal pain," Abdominal Imaging, 2015.

[32] F. N. Eko, G. E. Ryb, L. Drager, E. Goldwater, J. J. Wu, and T. C. Counihan, "Ideal timing of surgery for acute uncomplicated appendicitis," North American Journal of Medical Sciences, vol. 5, no. 1, pp. 22-27, 2013.
[33] M. Busch, F. S. Gutzwiller, S. Aellig, R. Kuettel, U. Metzger, and U. Zingg, "In-hospital delay increases the risk of perforation in adults with appendicitis," World Journal of Surgery, vol. 35, no. 7, pp. 1626-1633, 2011.

[34] S. Partelli, S. Beg, J. Brown, S. Vyas, and H. M. Kocher, "Alteration in emergency theatre prioritisation does not alter outcome for acute appendicitis: comparative cohort study," World Journal of Emergency Surgery, vol. 4, no. 1, article 22, 2009.

[35] P. G. Teixeira, E. Sivrikoz, K. Inaba, P. Talving, L. Lam, and D. Demetriades, "Appendectomy timing: waiting until the next morning increases the risk of surgical site infections," Annals of Surgery, vol. 256, no. 3, pp. 538-543, 2012. 


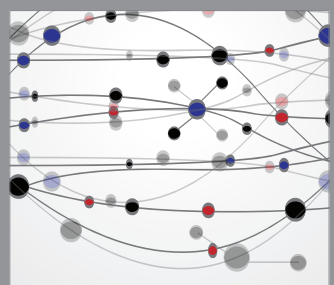

The Scientific World Journal
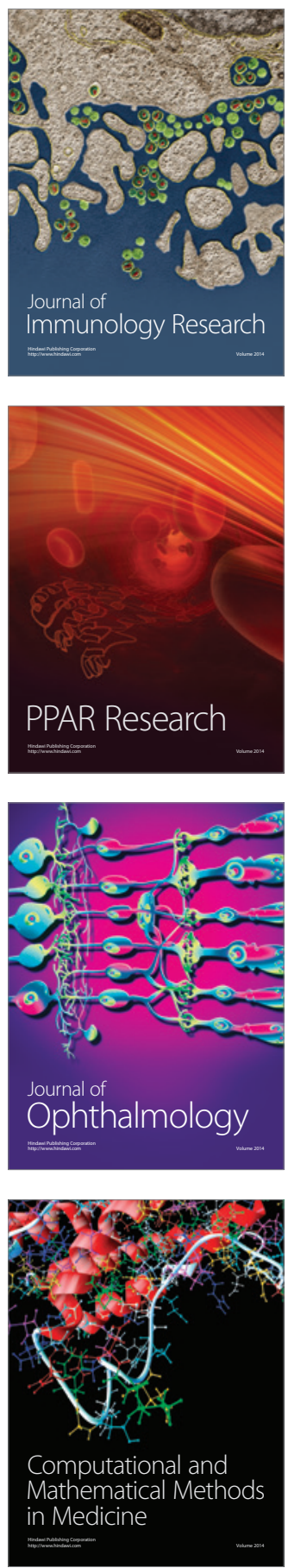

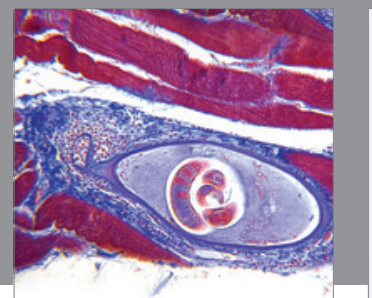

Gastroenterology

Research and Practice
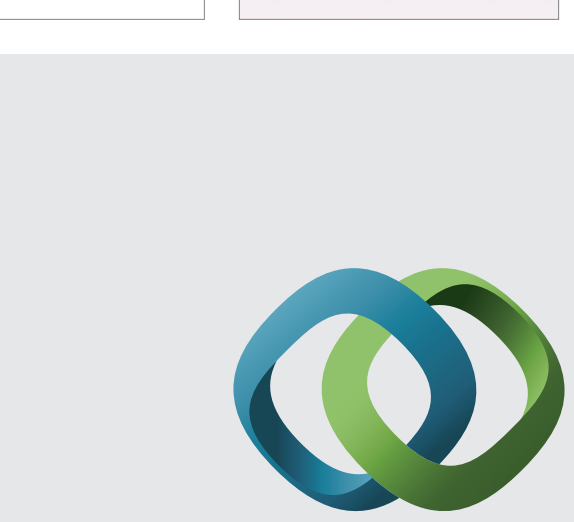

\section{Hindawi}

Submit your manuscripts at

http://www.hindawi.com
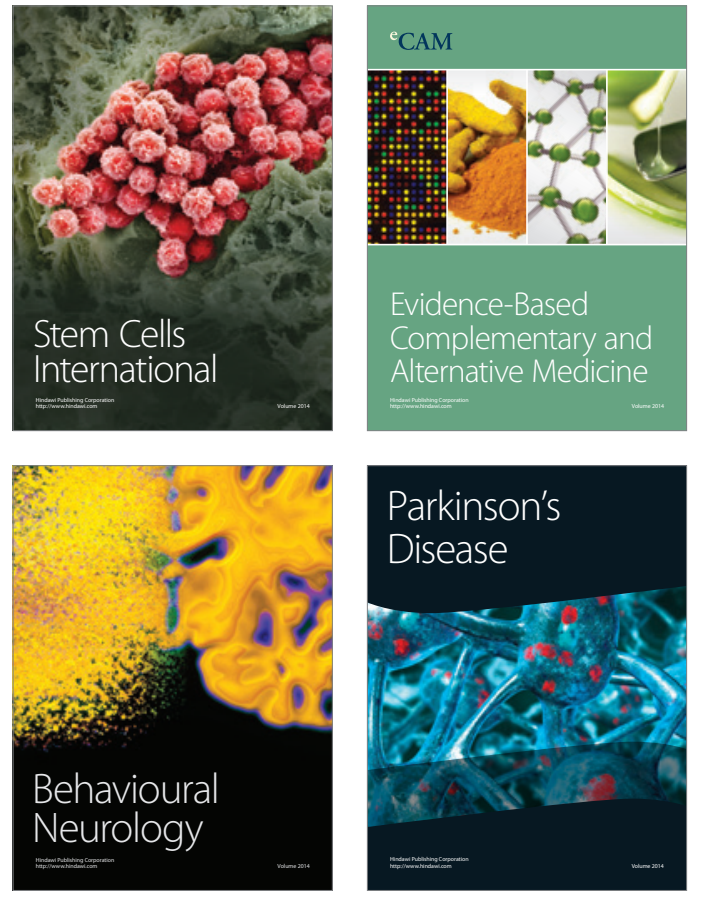
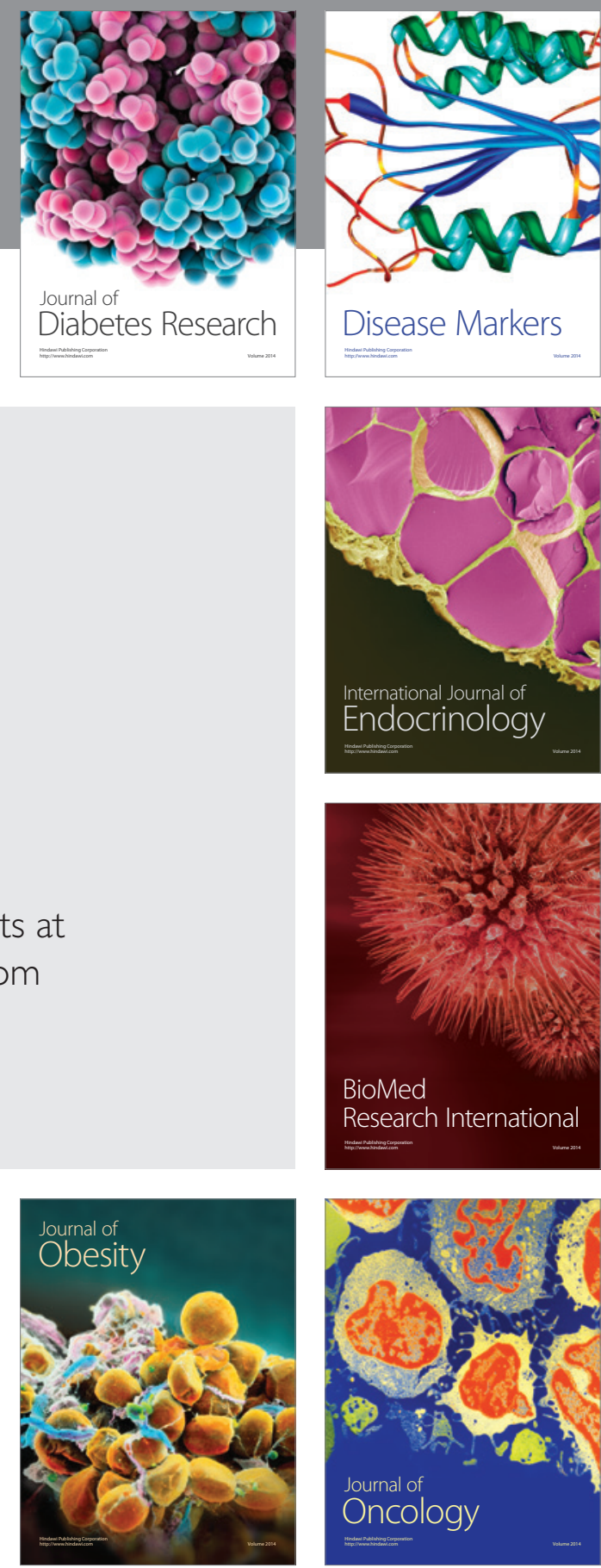

Disease Markers
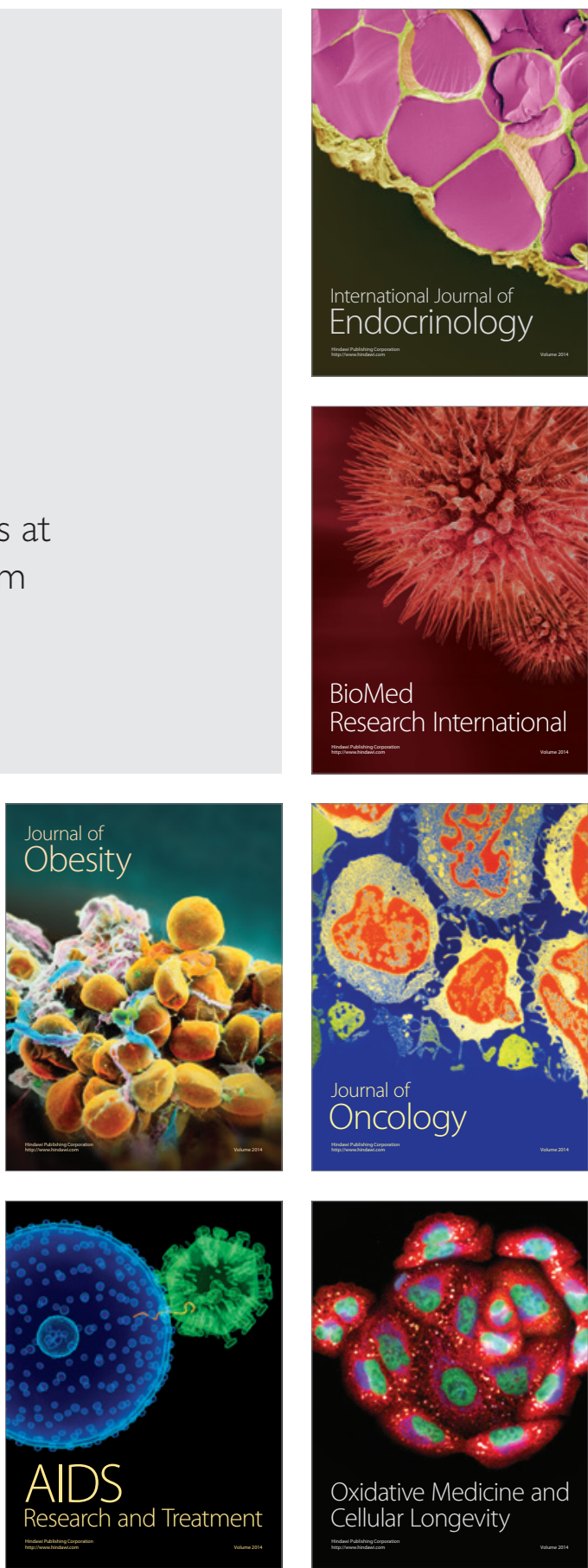